\title{
65 \\ The View in Tasmania and the Influence in Queensland
}

When the big Queensland office was about to renovate its inner-city site, the employees were given some influence over the design of the workplace. Their suggestions were accepted and put into practice; for example, airflow at the desks, tiles that reduced noise, good-quality chairs, levers to move keyboards up and down, and showers. The employees were very satisfied with their physical work environment.

When the company built a new site in Tasmania, it was modelled on the Queensland site because it had been such a success. The company did not think, however, that it was necessary to involve the workers this time. The whole site was designed without any worker influence at all. The office was very picturesquely located in a garden by a river, but only senior managers could see the view. The office only had small windows and the blinds were constantly drawn because the workers could not operate them - only top managers could open and shut their blinds. One worker commented: 'There is an outside world out there and people want to see it.... Why even have windows? Why do that to people? It feels like we're trapped.'

The workers accepted the reason for the blinds, which was to reduce eye-strain and headaches, but they had better solutions. Tinted windows, they said, would have had the same effect, still allowing them to look at the beautiful scenery every now and then. Management had not asked the employees and they had not thought of this themselves, which is why they were quite surprised that this replica of the appreciated site in an inner city location in Queensland met with such dissatisfaction beside a river in a park in Tasmania.

(Barnes, 2007) 